\title{
STRATEGI PENGEMBANGAN AGROWISATA PADA KELOMPOK TANI PELAKSANA SIPADU STUDI KASUS GAPOKTAN SRI SEDANA KABUPATEN KARANGASEM
}

\author{
Agroturism Development Strategies in The Sipadu Implementing Farmer Groups Case \\ Study of Gapoktan Sri Sedana in Karangasem Regency
}

\author{
Ni Wayan Purnami Rusadi' ${ }^{1)}$, I Gede Bagus Dera ${ }^{2)}$, I Dewa Ayu Puspitadewi ${ }^{3)}$ \\ ${ }^{1,2,3)}$ Dosen Politeknik Nasional Denpasar \\ E-mail : niwayanpurnamirusadi@gmail.com
}

Submit: 6 Juli 2020, Revised: 6 Agustus 2020, Accepted: Agustus 2020

\begin{abstract}
Sipadu is a Bali provincial government program which manage agricultural land resources in an integrated way as well as develops post-harvest management and other supporting activities. One strategy that needed to develop Sipadu is through agro-tourism system. The purpose of this study was to determine internal and external environmental factors, to make alternative strategies and priorities on how to develop agro-tourism, especially in the Sri Sedana farmers group as Sipadu implementers. Data was analyzed using the internal-external matrix (IE) analysis, matrix grand strategy, SWOT and QSPM analysis. The SO strategies include adding organic farming facilities whereas the WO strategies is to increase promotion of tour packages optimally by utilizing technology. One of the ST strategies is to collaborate with related agencies such as the Agriculture Office and the Tourism Office whilst the WT strategies is to collaborate with outside parties such as travel or school/campus. The most appropriate strategy to be prioritized based on the results of the QSPM analysis is to create an online sales service for products produced by Sipadu and other tourist objects in Tiyingtali village with a total value of 12.60 .
\end{abstract}

Keywords: Agrotourism; QSPM; Sipadu; Strategy and SWOT.

\begin{abstract}
ABSTRAK
Simantri merupakan program pemerintah Provinsi Bali yang dirintis sejak Tahun 2009 dan kini memiliki nama Sipadu. Sipadu tidak hanya melakukan pengelolaan sumber daya di lahan pertanian secara terintegrasi, namun mengembangkan pengelolaan pasca panen dan kegiatan penunjang lainnya. Dari fakta ini, diperlukan strategi untuk mengembangkan Sipadu yakni salah satunya dengan system agrowisata. Tujuan dari penelitian ini adalah untuk mengetahui analisis lingkungan internal dan eksternal, untuk membuat strategi alternatif dan juga prioritas bagaimana mengembangkan agrowisata khususnya di Gapoktan Sri Sedana sebagai pelaksana Sipadu. Analisis data dalam penelitian ini adalah analisis matriks internal-eksternal (IE), strategi besar matriks, SWOT dan dilanjutkan dengan analisis QSPM untuk menentukan prioritas strategi. Hasil penelitian ini menunjukkan strategi alternatif yang telah dirumuskan berdasarkan SWOT antara lain strategi SO salah satunya yakni menambah sarana pertanian organik. Strategi WO salah satunya meningkatkan promosi paket wisata secara optimal dengan memanfaatkan teknologi. Strategi ST salah satunya yaitu menjalin kerjasama dengan instansi terkait seperti Dinas Pertanian dan Dinas Pariwisata. Strategi WT
\end{abstract}


salah satunya menjalin kerjasama dengan pihak luar seperti travel dan sekolah/kampus. Strategi yang paling tepat untuk diprioritaskan berdasarkan hasil analisis QSPM adalah membuat layanan penjualan secara online untuk produk yang dihasilkan Sipadu dan objek wisata lain yang ada di Desa Tiyingtali dengan jumlah nilai 12.60. Strategi ini menekankan pada bagaimana langkah yang bias dilakukan dalam membuat layanan penjualan online untuk produk yang dihasilkan Sipadu dan objek wisata lain yang ada di Desa Tiyingtali. Seperti yang kita ketahui bersama perkembagan teknologi saat ini begitu pesat dan segala informasi dapat diakses melalui internet. Produk yang dihasilkan oleh Sipadu seperti hasil pertanian anorganik dan pupuk organik bias dipasarkan kekonsumen rumah tangga ataupun horeca (hotel, restaurant dan cafe) sesuai dengan Pergub Bali No. 99 Tahun 2018 tentang Pemasaran dan pemanfaatan produk pertanian, perikanan dan industri lokal Bali mewajibkan toko swalayan, hotel restoran dan katering untuk menyerap produk lokal.

Kata Kunci: Agrowisata; QSPM; Strategi; Sipadu; and SWOT.

\section{PENDAHULUAN}

Agrowisata merupakan bentuk khusus pariwisata di lokasi usahatani yang dapat berdampak ganda terhadap aspek sosial ekonomi dan permukaan areal (landscape) pedesaan (Budiasa, 2011; Baiano, 2020). Agrowisata bisa dikembangkan oleh individu petani yang memiliki minimal dua hektar lahan, rumah petani, sumberdaya air dan berminat untuk menjamu wisatawan. Selain individu atau sekelompok petani, koperasi pertanian, organisasi non-pemerintah, perguruan tinggi pertanian dapat mengembangkan pusat agrowisata (Maruti, 2009). Model agrowisata ini bisa menjadi pengembangan pertanian dan pariwisata di Bali secara berkelanjutan mengingat potensi yang dimiliki baik secara alam, budaya dan pelaksananya (Bachtiar, 2016). Menurut Budiarti (2013 dalam Palit 2017) agrowisata atau wisata pertanian didefinisikan sebagai rangkaian aktivitas perjalanan wisata yang memanfaatkan lokasi atau sektor pertanian mulai dari awal produksi sampai dengan diperoleh produk pertanian dalam berbagai sistem dan skala dengan tujuan memperluas pengetahuan, pemahaman, pengalaman, dan rekreasi di bidang pertanian. Pengembangan kawasan pertanian menjadi area agrowisata akan meningkatkan kunjungan wisatawan yang memberikan kontribusi peningkatan pendapatan masyarakat melaui jasa wisata (Budiarti, et. al, 2010 dalam Budiarti 2013).

Simantri merupakan upaya terobosan dalam mempercepat adopsi teknologi pertanian karena merupakan pengembangan model percontohan dalam percepatan alih 153 teknologi kepada masyarakat pedesaan (Darmayasa, 2014). Sistem ini menggabungkan pertanian, peternakan, perikanan, kehutanan dan ilmu lain yang terkait dengan pertanian dalam satu lahan sehingga diharapkan dapat sebagai salah satu solusi bagi peningkatan produktivitas lahan, program pembangunan dan konservasi lingkungan, serta pengembangan desa secara terpadu. Saat ini di Bali terdapat kelompoktani pelaksana sistem pertanian terintegrasi (SIMANTRI) yang kini telah berganti menjadi sistem pertanian terpadu (SIPADU) dan menjadi program unggulan pemerintah Provinsi Bali. Terbitnya Peraturan Gubernur (Pergub) No. 99 Tahun 2018 tentang Pemasaran dan Pemanfaatan Produk Pertanian, Perikanan dan Industri Lokal Bali memperkuat mewujudkan Sistem Pertanian Terpadu (Sipadu) Pemerintah Daerah. Pemerintah Provinsi Bali sendiripun sudah bergerak dalam hal melakukan kegiatan pertanian terpadu yang dikemas dalam program Simantri yang sudah berjalan sejak Tahun 2009, hingga sampai sekarang Tahun 2018 jumlah unit Simantri sebanyak 752 kelompok. Perkembangan jumlah kelompoktani pelaksana Sipadu di setiap kabupaten kota di Provinsi Bali juga menjadi potensi pengembangan agrowisata ke depannya. Data jumlah kelompoktani pelaksana Sipadu ditunjukkan pada Tabel 1.

Walaupun pemerintah daerah telah mencanangkan kelompoktani Sipadu sebagai salah satu kawasan agrowisata, kawasan wisata ini belum terlihat mampu memberi kemajuan yang signifikan dalam 
mengoptimalkan potensi yang ada, hal ini menimbulkan adanya ketimpangan perkembangan obyek wisata dan daya tarik wisata yang kurang merata serta kurang berpihak kepada pemberdayaan masyarakat khususnya petani ( $\mathrm{Bi}$ et al., 2020; Song et al., 2020; Yang, 2018). Dalam rangka mengoptimalkan potensi yang ada serta meningkatkan kunjungan wisatawan diperlukan suatu strategi dalam upaya untuk mengembangkan sektor pariwisata agrowisata (Pulido-Fernández et al., 2019; Velempini and Martin, 2019; Yang et al., 2010). Strategi ini diharapkan mampu mengoptimalkan dan meningkatkan pendapatan masyarakat lokal, disamping tetap mempertahankan keberlangsungan pertanian dalam pembangunan pariwisata
(Pongpattananurak, 2018; Sanches-Pereira et al., 2017). Bertolak dari potensi dan masalah yang ada pada kawasan tersebut, maka diangkat dalam suatu penelitian tentang strategi pengembangan agrowisata pada Gapoktan Sri Sedana di Desa Tiyingtali, Kecamatan Abang, Kabupaten Karangasem. Dengan demikian potensi yang ada pada kawasan Agrowisata tersebut dapat dikembangkan semaksimal mungkin dan dapat mendatangkan keuntungan bagi banyak pihak (FolgadoFernández et al., 2019; Kaswanto, 2015; Sharpley, 2002). Tujuan dari penelitian ini yaitu untuk menganalisis strategi pengembangan agrowisata pada kelompoktani pelaksana SIPADU studi kasus Gapoktan Sri Sedana Kabupaten Karangasem .

Tabel 1. Data Perkembangan Simantri/Sipadu dari Tahun 2009 sampai 2018

\begin{tabular}{|c|c|c|c|c|c|c|c|c|c|c|c|c|}
\hline \multirow{2}{*}{$\begin{array}{c}\text { Kabupaten/ } \\
\text { Kota }\end{array}$} & \multicolumn{11}{|c|}{ Tahun } & \multirow[b]{2}{*}{ Total } \\
\hline & 2009 & 2010 & 2011 & 2012 & 2013 & 2014 & 2015 & $\begin{array}{c}\text { AP } \\
2015\end{array}$ & 2016 & 2017 & 2018 & \\
\hline Badung & 1 & 1 & 10 & 5 & 9 & 7 & 6 & & 14 & 5 & & 58 \\
\hline Buleleng & 4 & 12 & 26 & 20 & 21 & 19 & 5 & & 14 & 15 & 14 & 150 \\
\hline Bangli & 1 & 6 & 18 & 20 & 14 & 8 & 6 & & 5 & 8 & 5 & 91 \\
\hline Denpasar & & 1 & 4 & 3 & & & & & & & & 8 \\
\hline Gianyar & 1 & 2 & 21 & 20 & 11 & 9 & 6 & 1 & 7 & 5 & 4 & 87 \\
\hline Jembrana & 1 & 2 & 12 & 12 & 11 & 11 & 6 & & 10 & 8 & 4 & 77 \\
\hline Karangasem & 1 & 9 & 22 & 12 & 10 & 7 & 6 & & 15 & 12 & & 94 \\
\hline Klungkung & & 3 & 21 & 12 & 8 & 7 & 3 & & 6 & 7 & 5 & 72 \\
\hline Tabanan & 1 & 4 & 16 & 21 & 10 & 15 & 7 & 1 & 12 & 11 & 17 & 115 \\
\hline Jumlah & 10 & 40 & 150 & 125 & 94 & 83 & 45 & 2 & 83 & 71 & 49 & 752 \\
\hline
\end{tabular}

Sumber : Dinas Pertanian Tanaman Pangan dan Hortikultura Provinsi Bali, 2018

\section{METODE PENELITIAN}

Penentuan lokasi penelitian dilakukan pada Gapoktan Sri Sedana di Tiyingtali, Kecamatan Abang, Kabupaten Karangasem, Provinsi Bali. Pemilihan lokasi penelitian Gapoktan Sri Sedana ini dilakukan secara sengaja (purposive) dengan pertimbangan sebagai berikut:
1. Adanya lahan pada Gapoktan Sri Sedana yang dikembangkan sebagai lahan pertanian organik.

2. Agrowisata di Gapoktan Sri Sedana ini didukung oleh pengembangan objek wisata lain yang ada di lingkungan Desa Tiyingtali

3. Lokasi Gapoktan Sri Sedana memiliki panorama yang indah karena berhadapan 
langsung dengan pemandangan Gunung Agung.

Waktu penelitian selama empat bulan yang dilaksanakan dari tanggal 2 Desember 2019 sampai dengan 29 Februari 2020. Penentuan populasi dalam penelitian ini dibagi menjadi tiga populasi yaitu populasi internal agrowisata, eksternal agrowisata dan masyarakat Desa Tiyingtali dimana di dalam penentuan setiap variabel menggunakan Focuss Group Discussion (FGD). Sumber data yang digunakan adalah data primer dan data sekunder. Data primer adalah data yang diperoleh secara langsung dari lokasi penelitian, yaitu dari Gapoktan Sri Sedana di Desa Tiyingtali, Kecamatan Abang, Kabupaten Karangasem, Provinsi Bali. Data sekunder adalah data yang diperoleh dari berbagai pustaka ilmiah yang mendukung. Berbagai pustaka ilmiah yang mendukung digunakan sebagai dasar atau pedoman dalam penentuan faktor-faktor internal dan eksternal agrowisata yang digunakan untuk menyusun matrik SWOT. Jenis data yang digunakan dalam penelitian ini adalah data kualitatif dan data kuantitatif. Data kualitatif merupakan data yang menggambarkan kondisi Kelompoktani Sipadu Angsoka beserta segala kegiatannya guna mendukung data kuantitatif. Metode pengumpulan data menggunakan tiga metode yaitu wawancara, observasi, Focuss Group Disscussion (FGD). Menurut Pearce dan Robinson (1997), yang dimaksud faktor-faktor analisis SWOT adalah strengths (kekuatan), weakness (kelemahan), opportunity (peluang) dan threats (ancaman). Variabel, indikator dan pengukuran yang digunakan dalam penelitian Strategi Pengembangan Agrowisata pada Gapoktan Sri Sedana di Tiyingtali, Kecamatan Abang, Kabupaten Karangasem, Provinsi Bali disajikan pada Tabel 2.

Adapun analisis data pada Strategi Pengembangan diantaranya sebagai berikut,

1. Analisis Lingkungan Internal dan Eksternal Identifikasi lingkungan internal dan eksternal digunakan untuk menganalisis faktor-faktor lingkungan internal dan eksternal agrowisata sehingga dapat diidentifikasi sejauh mana kekuatan, kelemahan dan peluang, ancaman yang dimiliki agrowisata tersebut.

2. Matriks Internal-Eksternal (IE)

Matriks IE digunakan untuk menentukan total skor dari matrik IFE dan matrik EFE yang telah dihasilkan dari matrik internal dan eksternal.

3. Analisis Matriks Grand Strategy

Matriks Grand Strategy merupakan tahapan pencocokan (matching stage) pada proses formulasi strategi.

4. Analisis SWOT

Analisis SWOT (Strenghts, Weakness, Opportunities, Threats) adalah identifikasi berbagai faktor secara sistematis untuk merumuskan strategi perusahaan (Rangkuti, 2005).

5. Analisis QSPM (Quantitative Strategic Planning Matrix)

Teknik QSPM secara objektif mengindikasikan alternatif strategi mana yang terbaik. QSPM menggunakan input dari analisis tahap matriks IE dan matriks SWOT untuk menentukan secara objektif di antara alternatif strategi.

\section{HASIL DAN PEMBAHASAN}

Lingkungan agrowisata dalam hal ini dapat dibagi menjadi dua yaitu dipengaruhi oleh faktor internal dan eksternal agrowisata. Berdasarkan hasil Focuss Group Discussion (FGD), faktor internal dan faktor eksternal akan disajikan pada Tabel 3 dan Tabel 4 sebagai berikut.

Faktor internal akan menentukan arah pengembangan terbaik bagi pengembangan agrowisata. Identifikasi kekuatan dan kelemahan internal agrowisata akan menjadikan penentu dalam menentukan strategi pengembangan yang tepat.

Dalam merumuskan strategi, maka terlebih dahulu harus melakukan analisis lingkungan. Identifikasi lingkungan mencangkup analisis dan diagnostik lingkungan sehingga penyusun strategi mampu mengetahui kekuatan-kekuatan dan kelemahan-kelemahan perusahaan (Supriyono, 1998). Matriks SWOT digunakan untuk merumuskan alternatif strategi yang menjadi kunci 
keberhasilan dalam pengembangan Agrowisata Gapoktan Sri Sedana pada Tabel 5.

Dari hasil perumusan analisis SWOT pada tabel 5, diperoleh 13 strategi yang terdiri dari 4 alternatif strategi SO, 4 strategi WO, 3 strategi ST dan 2 strategi WT yang dapat diterapkan di Agrowisata Kelompoktani Angsoka, dari 13 strategi tersebut dianalisis dengan analisis QSPM sehingga dapat diketahui strategi mana yang lebih didahulukan untuk diterapkan. Jumlah nilai total attractiveness (TAS) akan menentukan strategi mana yang didahulukan, lebih jelasnya tertera pada Tabel 6 berikut.

Tabel 2. Variabel, Indikator dan Pengukuran Pengembangan Agrowisata

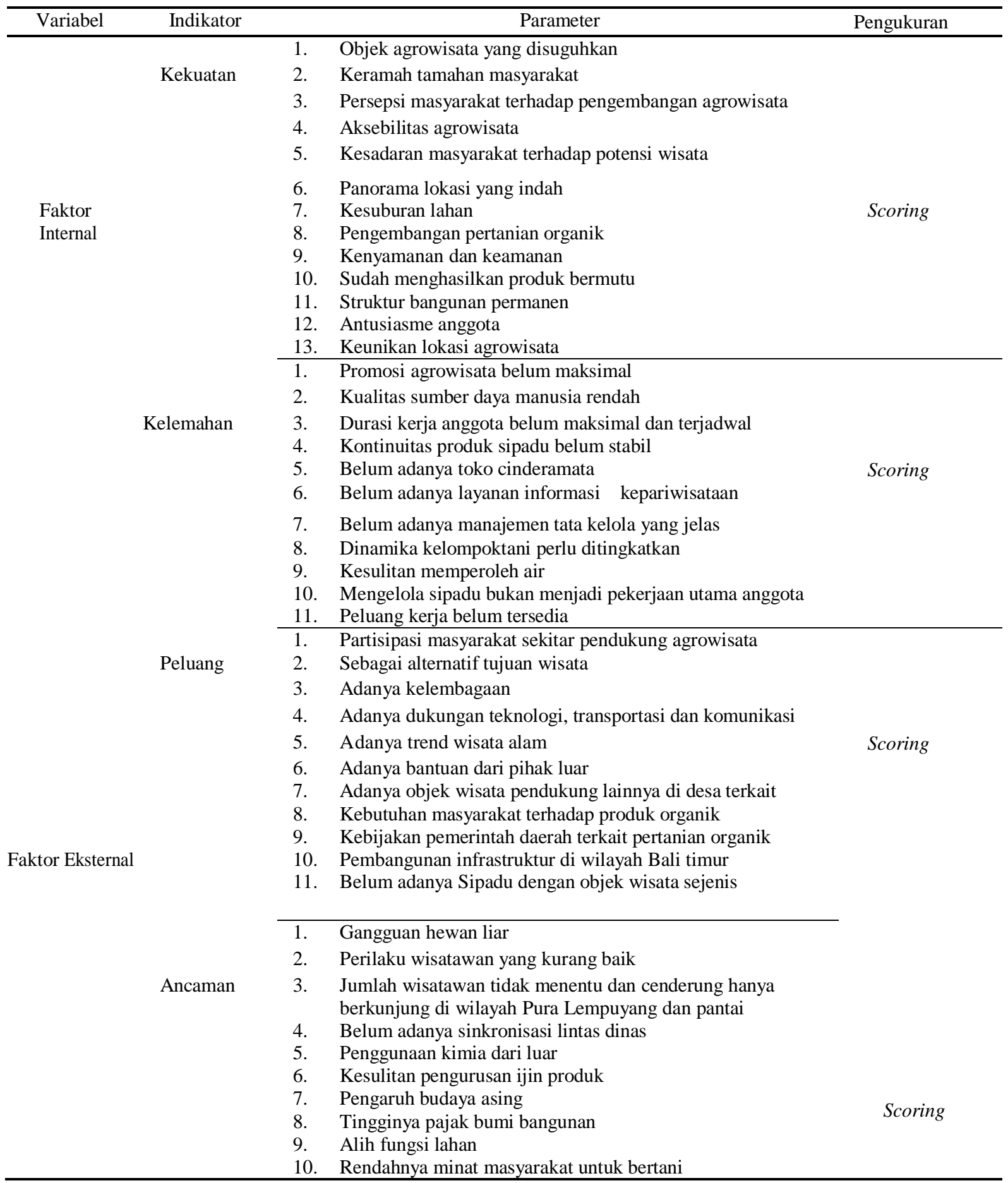


Tabel 3. Faktor Internal Agrowisata Kelompoktani Angsoka

\begin{tabular}{|c|c|c|c|}
\hline No & Identifikasi Faktor Internal & Kekuatan & Kelemahan \\
\hline 1 & Objek agrowisata yang disuguhkan & $\sqrt{ }$ & \\
\hline 2 & Keramah tamahan masyarakat & $\sqrt{ }$ & \\
\hline 3 & Persepsi masyarakat terhadap pengembangan agrowisata & $\sqrt{ }$ & \\
\hline 4 & Aksebilitas agrowisata & $\sqrt{ }$ & \\
\hline 5 & Kesadaran Masyarakat terhadap potensi wisata & $\sqrt{ }$ & \\
\hline 6 & Panorama lokasi yang indah & $\sqrt{ }$ & \\
\hline 7 & Kesuburan lahan & $\sqrt{ }$ & \\
\hline 8 & Pengembangan pertanian organik & $\sqrt{ }$ & \\
\hline 9 & Kenyamanan dan keamanan & $\sqrt{ }$ & \\
\hline 10 & Sudah menghasilkan produk bermutu & $\sqrt{ }$ & \\
\hline 11 & Struktur bangunan permanen & $\sqrt{ }$ & \\
\hline 12 & Antusiasme anggota & $\sqrt{ }$ & \\
\hline 13 & Keunikan lokasi agrowisata & $\sqrt{ }$ & \\
\hline 14 & Promosi agrowisata belum maksimal & & $\sqrt{ }$ \\
\hline 15 & Kualitas sumber daya manusia rendah & & $\sqrt{ }$ \\
\hline 16 & Durasi kerja anggota belum maksimal dan terjadwal & & $\sqrt{ }$ \\
\hline 17 & Kontinuitas produk Sipadu belum stabil & & $\sqrt{ }$ \\
\hline 18 & Belum adanya toko cindera mata & & $\sqrt{ }$ \\
\hline 19 & Belum adanya layanan informasi kepariwisataan & & $\sqrt{ }$ \\
\hline 20 & Belum adanya manajemen tata kelola yang jelas & & $\sqrt{ }$ \\
\hline 21 & Dinamika kelompoktani perlu ditingkatkan & & $\sqrt{ }$ \\
\hline 22 & Kesulitan memperoleh air & & $\sqrt{ }$ \\
\hline 23 & Mengelola Sipadu bukan menjadi pekerjaan utama & & $\sqrt{ }$ \\
\hline 24 & anggota Peluang kerja belum tersedia & & $\sqrt{ }$ \\
\hline
\end{tabular}

Berdasarkan hasil analisis QSPM jumlah nilai total attractiveness (TAS) terbesar adalah strategi yang menyatakan "Membuat layanan penjualan secara online untuk produk yang dihasilkan Sipadu dan objek wisata lain yang ada di Desa Tiyingtali (WO3)" dengan jumlah nilai 12.60. Strategi ini menekankan pada bagaimana langkah yang bisa dilakukan dalam membuat layanan penjualan online untuk produk yang dihasilkan Sipadu dan objek wisata lain yang ada di Desa Tiyingtali. Seperti yang kita ketahui bersama perkembagan teknologi saat ini begitu pesat dan segala informasi dapat diakses melalui internet. Produk yang dihasilakn oleh Sipadu seperti hasil pertanian organik dan pupuk organik bisa dipasarkan ke konsumen rumah tangga ataupun horeca (hotel, restaurant dan cafe) sesuai dengan Pergub Bali No. 99 Tahun 2018. 
Tabel 4. Faktor Eksternal Agrowisata Kelompoktani Angsoka

\begin{tabular}{|c|c|c|c|}
\hline No. & Identifikasi Faktor Eksternal & Peluang & Ancaman \\
\hline 1 & Partisipasi masyarakat sebagai pendukung agrowisata & $\sqrt{ }$ & \\
\hline 2 & Sebagai alternatif tujuan wisata & $\sqrt{ }$ & \\
\hline 3 & Adanya kelembagaan & $\sqrt{ }$ & \\
\hline 4 & $\begin{array}{l}\text { Adanya dukungan teknologi, transportasi dan } \\
\text { komunikasi }\end{array}$ & $\sqrt{ }$ & \\
\hline 5 & Adanya trend wisata alam & $\sqrt{ }$ & \\
\hline 6 & Adanya bantuan dari pihak luar & $\sqrt{ }$ & \\
\hline 7 & $\begin{array}{l}\text { Adanya objek wisata pendukung lainnya di desa } \\
\text { terkait }\end{array}$ & $\sqrt{ }$ & \\
\hline 8 & Kebutuhan masyarakat terhadap produk organik & $\sqrt{ }$ & \\
\hline 9 & Kebijakan pemerintah daerah terkait pertanian organik & $\sqrt{ }$ & \\
\hline 10 & Pembangunan infrastruktur di wilayah Bali Timur & $\sqrt{ }$ & \\
\hline 11 & Belum ada Sipadu dengan objek wisata sejenis & $\sqrt{ }$ & \\
\hline 12 & Gangguan hewan liar & & $\sqrt{ }$ \\
\hline 13 & Perilaku wisatawan yang kurang baik & & $\sqrt{ }$ \\
\hline 14 & $\begin{array}{l}\text { Jumlah wisatawan tidak menentu dan cenderung } \\
\text { hanya berkunjung di wilayah Pura Lempuyang dan } \\
\text { pantai }\end{array}$ & & $\sqrt{ }$ \\
\hline 15 & Belum adanya sinkronisasi lintas dinas & & $\sqrt{ }$ \\
\hline 16 & Penggunaan kimia dari luar & & $\sqrt{ }$ \\
\hline 17 & Kesulitan pengurusan perijinan produk & & $\sqrt{ }$ \\
\hline 18 & Pengaruh budaya asing & & $\sqrt{ }$ \\
\hline 19 & Tingginya pajak bumi bangunan & & $\sqrt{ }$ \\
\hline 20 & Alih fungsi lahan & & $\sqrt{ }$ \\
\hline 21 & Rendahnya minat masyarakat untuk bertani & & $\sqrt{ }$ \\
\hline
\end{tabular}




\section{Tabel 5. Penentuan Alternatif Strategi Dengan Analisis SWOT}

\begin{tabular}{|c|c|c|}
\hline & Kekuatan (S) & Kelemahan $(\mathbf{W})$ \\
\hline Faktor Internal & $\begin{array}{l}\text { 1. Objek agrowisata yang disuguhkan } \\
\text { 2. Keramah tamahan masyarakat } \\
\text { 3. Persepsi masyarakat terhadap } \\
\text { pengembangan wisata } \\
\text { 4. Aksebilitas agrowisata } \\
\text { 5. Kesadaran masyarakat terhadap } \\
\text { potensi wisata } \\
\text { 6. Panorama lokasi yang indah } \\
\text { 7. Kesuburan tanah } \\
\text { 8. Pengembangan pertanian organik } \\
\text { 9. Kenyamanan dan keamanan } \\
\text { 10. Sudah menghasilkan produk } \\
\text { 11. Struktur bangunan permanen } \\
\text { 12. Antusiasme anggota } \\
\text { 13. Keunikan lokasi agrowisata }\end{array}$ & $\begin{array}{l}\text { 1. Promosi agrowisata belum maksimal } \\
\text { 2. Jumlah sumber daya manusia rendah } \\
\text { 3. Durasi kerja anggota belum maksimal dan } \\
\text { terjadwal } \\
\text { 4. Kontinuitas produk Sipadu belum stabil } \\
\text { 5. Belum adanya toko cenderamata } \\
\text { 6. Belum adanya layanan informasi } \\
\text { kepariwisataan } \\
\text { 7. Belum adanya manajemen tata kelola } \\
\text { 8. } \begin{array}{l}\text { Ding jelas } \\
\text { ditingkatkan kelompoktani perlu }\end{array} \\
\text { 9. Kesulitan memperoleh air } \\
\text { 10. Mengelola Sipadu bukan menjadi } \\
\text { 11. Pekerjaan utama anggota } \\
\text { 11. Peluang kerja belum tersedia }\end{array}$ \\
\hline
\end{tabular}

Peluang (O)

1. Partisipasi masyarakat sekitar sebagai pendukung agrowisata

2. Sebagai alternatif tujuan wisata

3. Adanya kelembagaan

4. Adanya dukungan teknologi, transportasi dan komunikasi

5. Adanya trend wisata alam

6. Adanya bantuan dari pihak luar

7. Adanya objek wisata pendukung lainnya di desa terkait

8. Kebutuhan masyarakat terhadap produk organik

9. Kebijakan pemerintah daerah terkait pertanian organik

10. Pembangunan infrastruktur di wilayah Bali Timur

11. Belum adanya Sipadu dengan objek wisata sejenis

\section{Strategi SO}

Strategi WO

1. Menambah sarana pertanian organik 1 (SO1)

2. Menambah ragam kegiatan edukasi pertanian organik (SO2)

3. Mengoptimalkan pengolahan pasca panen produk Sipadu (SO3)

4. Mengoptimalkan sarana penunjang wisata (tempat swafoto) (SO4)

Ancaman (T) Strategi ST

. Gangguan hewan liar

2. Perilaku wisatawan yang kurang baik

3. Jumlah wisatawan tidak menentu dan cenderung hanya berkunjung di wilayah Pura Lempuyang dan pantai

1. Membuat pagar pelindung di sekitaran lokasi agrowisata (ST1)

2. Menjalin kerjasama dengan instansi terkait seperti Dinas Pertanian dan 2 . Dinas Pariwisata (ST2)

3. Mensosialisasikan pertanian berkelanjutan (ST3)
Meningkatkan promosi paket wisata secara optimal dengan memanfaatkan teknologi (WO1)

2. Mengadakan pelatihan team building bagi kelompoktani dan anggota sekaa teruna/teruni dalam pengembangan agrowista (WO2)

3. Membuat layanan penjualan secara online untuk produk yang dihasilkan Sipadu dan objek wisata lain yang ada di Desa Tiyingtali (WO3)

4. Mengatur pengelolaan pengembangan desa wisata dengan pihak pemeritah desa terkait (WO4)

4. Belum adanya sinkronisasi lintas dinas

5. Penggunaan kimia dari luar

6. Kesulitan pengurusan perijinan produk

7. Pengaruh budaya asing

8. Tingginya pajak bumi bangunan

9. Alih fungsi lahan

10. Rendahnya minat masyarakat untuk bertani 
Tabel 6. Hasil QSPM Agrowisata Kelompoktani Angsoka

\begin{tabular}{|c|c|c|}
\hline No & Strategi & Nilai TAS \\
\hline 1. & $\begin{array}{l}\text { Membuat layanan penjualan secara online untuk produk yang } \\
\text { dihasilkan Sipadu dan objek wisata lain yang ada di Desa Tiyingtali } \\
\text { (WO3) }\end{array}$ & 12.60 \\
\hline 2. & $\begin{array}{l}\text { Mengatur pengelolaan pengembangan desa wisata dengan pihak } \\
\text { pemerintah desa terkait (WO4) }\end{array}$ & 12.51 \\
\hline 3. & Menambah sarana pertanian organik (SO1) & 12.25 \\
\hline 4. & $\begin{array}{l}\text { Mengadakan pelatihan team building bagi kelompoktani dan anggota } \\
\text { sekaa teruna/teruni dalam pengembangan agrowisata (WO2) }\end{array}$ & 12.23 \\
\hline 5. & Mengoptimalkan sarana penunjang wisata (tempat swafoto) (SO4) & 12.03 \\
\hline 6. & $\begin{array}{l}\text { Menjalin kerjasama dengan instansi terkait seperti Dinas Pertanian } \\
\text { dan Dinas Pariwisata (ST2) }\end{array}$ & 12.01 \\
\hline 7. & $\begin{array}{l}\text { Menjalin kerjasama dengan pihak luar seperti travel maupun } \\
\text { sekolah/kampus (WT1) }\end{array}$ & 11.75 \\
\hline 8. & $\begin{array}{l}\text { Meningkatkan promosi paket wisata secara optimal dengan } \\
\text { memanfaatkan teknologi (WO1) }\end{array}$ & 11.73 \\
\hline 9. & Mensosialisasikan pertanian berkelanjutan (ST3) & 11.69 \\
\hline 10. & Menambah ragam kegiatan edukasi pertanian organik (SO2) & 11.51 \\
\hline 11. & Mengoptimalkan pengolahan pasca panen produk Sipadu (SO3) & 11.47 \\
\hline 12. & Membuat peraturan bagi pengunjung (WT2) & 11.18 \\
\hline 13. & Membuat pagar pelindung di sekitaran lokasi agrowisata (ST1) & 10.79 \\
\hline
\end{tabular}

\section{KESIMPULAN DAN SARAN}

\section{Kesimpulan}

Berdasarkan hasil analisis data dan pembahasan maka dapat disimpulkan bahwa Strategi SO yakni menambah sarana pertanian organik; menambah ragam kegiatan edukasi pertanian organik; mengoptimalkan pengolahan pasca panen bunga matahari; mengoptimalkan sarana penunjang wisata (tempat swafoto). Strategi WO diantaranya meningkatkan promosi paket wisata secara optimal dengan memanfaatkan teknologi; mengadakan pelatihan team building bagi kelompoktani dan anggota sekaa teruna/teruni dalam pengembangan agrowisata; membuat layanan penjualan secara online untuk produk yang dihasilkan Sipadu dan objek wisata lain yang ada di Dsa Tiyingtali; mengatur pegelolaan pengembangan desa wisata dengan pihak pemerintah desa terkait. Strategi ST yaitu membuat pagar pelindung di sekitaran lokasi agrowisata; menjalin kerjasama dengan instansi terkait seperti Dinas Pertanian dan Dinas Pariwisata; mensosialisasikan pertanian berkelanjutan. Strategi WT diantaranya menjalin kerjasama dengan pihak luar seperti travel maupun sekolah/kampus; membuat peraturan bagi pengunjung.

Strategi yang paling tepat untuk diprioritaskan berdasarkan hasil analisis QSPM adalah membuat layanan penjualan secara online untuk produk yang dihasilkan Sipadu dan objek wisata lain yang ada di Desa Tiyingtali. Strategi ini menekankan pada langkah yang bisa dilakukan dalam membuat layanan penjualan online untuk produk yang dihasilkan Sipadu dan objek wisata lain yang ada di Desa Tiyingtali.

\section{Saran}

Pemerintah Kabupaten Karangasem bersama dengan Dinas Pertanian Tanaman Pangan dan Hortilutura Provinsi Bali, 
sebaiknya tidak hanya mengembangkan kelompoktani pelaksana Sipadu ini sebagai praktik pengelolaan sumber daya yang tersedia di lahan pertanian secara terintegrasi, namun juga membuka peluang kerja bagi kelompoktani dengan mengembangkan pengelolaan pasca panen dan kegiatan penunjang lainnya.

Untuk pihak agrowisata diharapkan merancang program pengembangan, untuk program jangka pendek dalam pengembangan aktivitas edukasi agrowisata dan melengkapi sarana prasarana, serta untuk jangka panjang adalah memperkenalkan agrowisata ini melalui promosi online ataupun offline seperti melalui travel dan sekolah/kampus.

Diperlukannya kerjasama antar lembaga pemerintah desa, sekaa teruna/teruni dan kelompoktani dalam pengembangan agrowisata dengan pihak swasta dalam pengembangan agrowisata. Misalnya dalam hal pembinaan sumber daya manusia dan promosi agrowisata.

\section{DAFTAR PUSTAKA}

Bachtiar, A.R. 2016. Persepsi Masyarakat dan Strategi Pengembangan Agrowisata Salak di Desa Sibetan Kecamatan Bebandem Kabupaten Karangasem Bali. Jurnal Manajemen Agribisnis. Universitas Udayana. Denpasar

Budiarti T., Suwarto, Muflikhati I. 2013. Pengembangan Agrowisata Berbasis Masyarakat Pada Usaha Tani Terpadu Meningkatkan Kesejahteraan Petani dan Keberlanjutan Sistem Pertanian. Jurnal Ilmu Pertanian Indonesia. Institut Pertanian Bogor. Bogor

Budiasa, I W. 2011. Konsep dan Potensi Pengembangan Agrowisata di Bali. Jurnal Dwijen Agro. Universitas Dwijendra. Denpasar

Baiano, A., 2020. Edible insects: An overview on nutritional characteristics, safety, farming, production technologies, regulatory framework, and socioeconomic and ethical implications. Trends in Food Science \& Technology 100 , $35-50$. https://doi.org/10.1016/j.tifs.2020.03.0 $\underline{40}$

Bi, J.-W., Liu, Y., Li, H., 2020. Daily tourism volume forecasting for tourist attractions. Annals of Tourism Research 83, 102923. https://doi.org/10.1016/j.annals.2020.1 02923

Darmayasa, D. N. 2014. Tingkat Keberhasilan Sistem Pertanian Terintegrasi di Kabupaten Tabanan. Jurnal Dwijen Agro. Universitas Dwijendra. Denpasar

Dinas Pertanian Tanaman Pangan dan Hortikultura Provinsi Bali. 2016. Data Perkembangan Simantri/Sipadu dari tahun 2009 sampai 2018. Denpasar

Folgado-Fernández, J.A., Campón-Cerro, A.M., Hernández-Mogollón, J.M., 2019. Potential of olive oil tourism in promoting local quality food products: A case study of the region of Extremadura, Spain. Heliyon 5, e02653.

https://doi.org/10.1016/j.heliyon.2019. $\underline{\mathrm{e} 02653}$

Kaswanto, 2015. Land Suitability for Agrotourism Through Agriculture, Tourism, Beautification and Amenity (ATBA) Method. Procedia Environmental Sciences 24, 35-38. https://doi.org/10.1016/j.proenv.2015.0 $\underline{3.006}$

Maruti, K.V. 2009. Agrotourism: Scope and Opprotunities for the Farmers in Maharashtra. Article Report. Dept. of Economics, Y.C. college. Pachwad Tal-Wai, Dist-Satara, State Maharashtra

Palit, Ireine Gratia, et al. 2017. Strategi Pengembangan Kawasan Agrowisata Rurukan. Jurnal Agri-Sosio Ekonomi Unsrat. Universitas Samratulangi. Manado

Pongpattananurak, N., 2018. Impacts from tourism development and agriculture on forest degradation in Thap Lan 
National Park and adjacent areas. Agriculture and Natural Resources 52, 290-297.

https://doi.org/10.1016/j.anres.2018.09 .013

Pulido-Fernández, J.I., Casado-Montilla, J., Carrillo-Hidalgo, I., 2019. Introducing olive-oil tourism as a special interest tourism. Heliyon 5, e02975. https://doi.org/10.1016/j.heliyon.2019. $\underline{\mathrm{e} 02975}$

Rangkuti, F. 2005. Analisis SWOT Teknik Membedah Kasus Bisnis. PT. Gramedia Pustaka Utama. Jakarta

Supriyono, R.A. 1998. Manajemen Strategis dan Kebijaksanaan Bisnis, Edisi kedua. BPFE-Yogyakarta. Yogyakarta

Sanches-Pereira, A., Onguglo, B., Pacini, H., Gómez, M.F., Coelho, S.T., Muwanga, M.K., 2017. Fostering local sustainable development in Tanzania by enhancing linkages between tourism and smallscale agriculture. Journal of Cleaner Production 162, 1567-1581. https://doi.org/10.1016/j.jclepro.2017.0 $\underline{6.164}$

Sharpley, R., 2002. Rural tourism and the challenge of tourism diversification: the case of Cyprus. Tourism Management 23, 233-244. https://doi.org/10.1016/S0261$\underline{5177(01) 00078-4}$

Song, H., Xie, K., Park, J., Chen, W., 2020. Impact of accommodation sharing on tourist attractions. Annals of Tourism Research $\quad 80, \quad 102820$. https://doi.org/10.1016/j.annals.2019.1 $\underline{02820}$

Velempini, K., Martin, B., 2019. Place-based education as a framework for tourism education in secondary schools: A case study from the Okavango Delta in Southern Africa. Journal of Hospitality, Leisure, Sport \& Tourism Education $\quad 25, \quad 100197$. https://doi.org/10.1016/j.jhlste.2019.10 $\underline{0197}$

Yang, Y., 2018. Understanding tourist attraction cooperation: An application of network analysis to the case of Shanghai, China. Journal of Destination Marketing \& Management 8 , 396-411. https://doi.org/10.1016/j.jdmm.2017.0 $\underline{8.003}$

Yang, Z., Cai, J., Sliuzas, R., 2010. Agrotourism enterprises as a form of multifunctional urban agriculture for periurban development in China. Habitat International 34, 374-385. https://doi.org/10.1016/j.habitatint.200 $\underline{9.11 .002}$ 